\title{
Covid-19, Classical Subjects and the Classroom: Teachers' Feedback from Summer 2020
}

\author{
Jessica Dixon
}

\begin{abstract}
The Classical Association Teaching Board (CATB) surveyed Classics teachers in the United Kingdom from $20^{\text {th }}$ August to $9^{\text {th }}$ September 2020 to gauge views about the impact on teaching of the national lockdown during the covid-19 pandemic. 164 teachers from both the state and independent sectors completed the survey. There were three areas of focus in the survey. First, the impact on pupils of the grade awarding process after the cancellation of GCSE and A Level examinations in 2020. Second, how confident teachers were in preparing for the 2021 examinations after the loss of five months of face-to-face teaching. Third, reactions to Ofqual's consultation process on changes to the format of the 2021 examinations. This article brings together the responses to the survey and details how the unprecedented closure of schools affected the teaching of Classics. It will also explain how the CATB continues to support Classics teachers and the teaching of classical subjects in UK schools.
\end{abstract}

Key words: Latin, Classical Civilisation, Ancient History, Ancient Greek, examinations, qualifications

Received: 1 October 2020, Accepted: 6 October 2020

The UK government announced on 18th March 2020 that in light of the 'increasingly extraordinary circumstances' that the country faced with the spread of coronavirus, schools would close on Friday 20th March until further notice (Department for Education, 2020a). Moreover, pupils would not sit exams that summer. Instead, teachers would use data such as mock exam results and their own judgement to submit a prediction of the grade each pupil would have achieved had they sat the exam. Ofqual would then '... combine this information with other relevant data, including prior attainment, and use this information to produce a calculated grade for each student, which will be a best assessment of the work they have put in' (Department for Education, 2020b). Ofqual and the exams boards promised to work with teachers' representatives and the teaching unions were happy that the Department for Education (DfE) and Ofqual recognised the professionalism of teachers in making these judgements (Bousted, 2020). Centre Assessed Grades (CAGs) were submitted by schools between 1st and 12th June 2020 (Ofqual, 2020a) and results for A Level were made public on 13th August and for GCSE on 20th August. In the meantime, on 7th August, The Guardian newspaper reported that up to $40 \%$ of teachers' grades had been downgraded, affecting nearly 300,000 grades (Adams, 2020). Such was the outpouring of outrage and anger that followed the publication of results on 13th August that five days later the government made a u-turn to award the CAGs which had originally been predicted by teachers. The process has caused stress and uncertainty for both pupils and teachers and has shaken the teaching profession's confidence in the DfE and Ofqual.

Teachers now face the further problem of how to prepare pupils for exams in 2021 after losing four months of face-to face teaching.

Author of correspondence: Jessica Dixon, E-mail: jdixon@los.ac

Cite this article: Dixon J, (2020). Covid-19, Classical Subjects and the Classroom: Teachers' Feedback from Summer 2020. The Journal of Classics Teaching 21, 60-65. https://doi.org/10.1017/S2058631020000501
The DfE and Ofqual consulted between 2nd and 16th July on adaptations to the current examination specifications to free up teaching time and to allow for the impact of future public health concerns on subject content and possible changes to the exam timetable (Department for Education, 2020c). However, only minimal changes were made and Amanda Brown, Deputy General Secretary at the National Union of Teachers, accused the government of 'having their head in the sand' (Brown, 2020). The only change for any of the four classical subjects as a result of this process was a reduction in examined content for just one: GCSE Ancient History (Ofqual, 2020b). Exams for all other classical subjects and levels remain the same. Therefore, teachers and pupils have been left to cover the same material as before for Latin, Ancient Greek and Classical Civilisation but in reduced time.

There is no doubt that the closure of schools and cancellation of exams have had significant consequences for students' education and the normal processes of teaching and assessment have been torn apart. Despite this, teachers across the profession have tried to maintain as normal an education as possible for their pupils, whilst themselves learning to adapt to online teaching methods. However, the stark variety in experience between those who have access to the internet and technology and those who do not has had a detrimental impact on the learning of thousands of pupils. Research conducted in April 2020 by the Sutton Trust, an education charity that fights for social mobility, found that pupils in independent schools were twice as likely as those in state schools to take part in daily online lessons (Cullinane \& Montacute, 2020). Moreover, according to Sir Peter Lampl, Chairman of the Sutton Trust, pupils from poorer homes faced a double disadvantage: not only were they less likely to be able to access online education, but they were more likely to have insufficient resources at home to support their learning (Lampl, quoted by Hall, 2020). These are truly extraordinary circumstances and the effects will be felt for years to come. 


\section{Method}

The Classical Association Teaching Board sought to examine the impact of the closure of schools on the Classics teaching community and gauge views about both the grade awarding process and the challenges faced in preparing pupils for the 2021 exams. An online survey (see appendix) designed by Jessica Dixon, Exams Officer for the CATB, and Arlene Holmes-Henderson, ${ }^{1}$ Outreach Officer for the Classical Association, opened on 20th August, after the GCSE grades were announced, and closed three weeks later. The survey was promoted through the Classical Association and Classics Library websites, social media and other teacher networks. 164 teachers responded.

Question 1: 'What type of school or college do you teach at?'

Over half (55\%) of the respondents taught at independent schools, with $30 \%$ at non-selective state schools, $11 \%$ at selective state schools and $4 \%$ in other educational settings.

Question 2: 'What subject/s do you teach?'

The subject most widely taught was GCSE Latin (73\%), followed by A Level Classical Civilisation (63\%), A Level Latin (60\%), GCSE Classical Civilisation (40\%) and GCSE Greek (40\%). The spread of responses across subject types and examination levels is good.

Grade awarding process

Question 3: 'What impact has the grade awarding process had on your students this year?'

The majority said neutral (47\%), with an almost equal split between those who said positive (23\%) and negative (21\%). However, when results were analysed for school sector, between state/state selective

\section{Q2: What subjects do you teach. Please tick all that apply.}

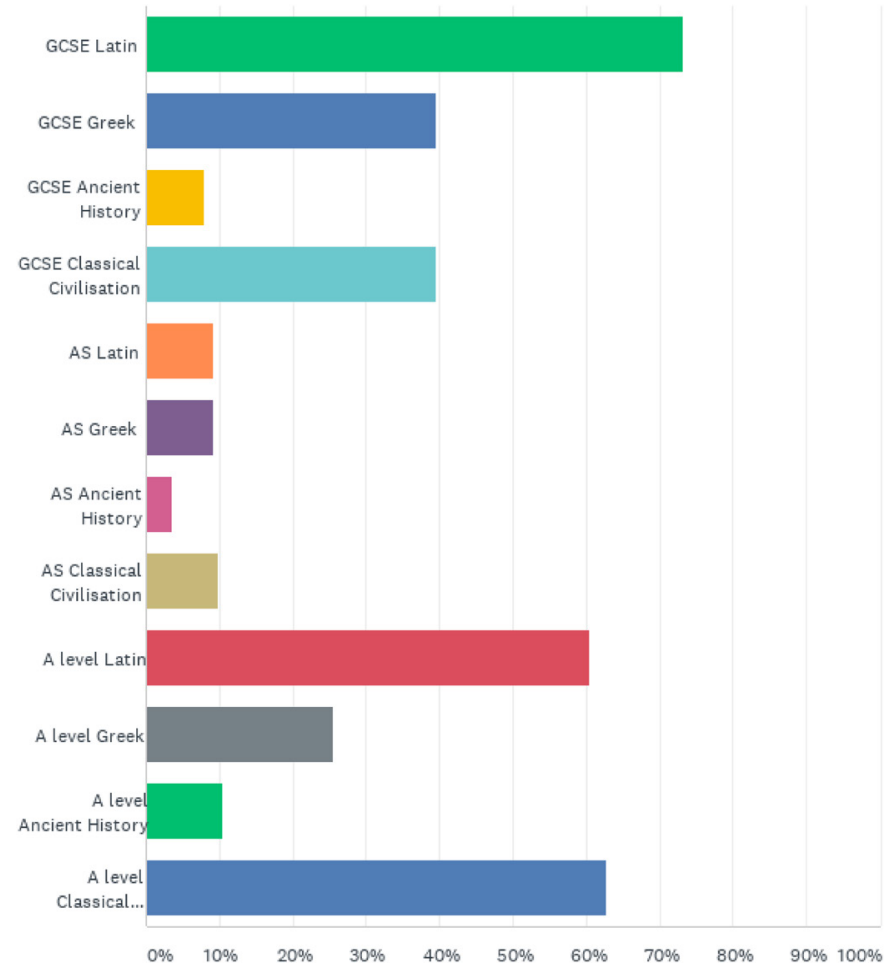

Graph 1: Classical subjects taught, by level, as reported by respondents in response to question 2. and independent school respondents, a greater number of state sector teachers reported a negative impact (28\%) than positive (14\%), whereas, in the independent sector, more said that it was positive (31\%) than negative (18\%). This finding supports media reports of state sector pupils being more adversely affected by the results process (Williams, 2020; Cowburn, 2020). Teachers were invited to provide comments in support of their answers. These showed that the process had only been neutral or positive after the u-turn on 17th August to award CAGs. Before this it had been overwhelmingly negative for many pupils. Upset and anger were the overriding feelings amongst respondents over the stress and frustration that the grade awarding process caused for pupils. Pupils were described as feeling 'cheated' and it was felt that the 'mental anguish of the uncertainty [of the process] ... was unforgiveable'.

Overall, the u-turn to award CAGs was seen as a good decision and preferable to Ofqual's algorithm. Nevertheless, some respondents felt that schools that carefully awarded CAGs based on school data were disadvantaged, whilst others were rewarded for being overly generous. There was also frustration over the inability of CAGs based on official whole school data to recognise pupils who had worked to improve since they sat their mock exams (some taken back in December 2019). The absence of moderation between schools meant there were significant differences in how schools determined their CAGs and there was a call for greater moderation of internal assessment between schools if this system is used again.

Others found it difficult to award grades accurately when the new qualifications for GCSE Classical Civilisation and Ancient History were only examined for the first time in 2019. A further problem was the blame that pupils who failed to achieve their desired grades placed on teachers. Some respondents commented on the burden that these complaints then placed on schools and teachers at an already difficult time as they prepared to reopen in September after six months' absence.

Some, however, thought that the absence of exams and the use of the algorithm benefitted their pupils. For example, respondents believed that small sets were 'rewarded', as teacher-predicted grades for classes of 15 or more were moderated by Ofqual against the historic grade profile of the school or college (Nye \& Thomson, 2020). This particularly seems to have benefited classical subjects, which tend to have smaller class sizes, especially in independent schools. The average A Level class size was reported in the survey as 1-5 in Latin (86\%), Greek (92\%) and Classical Civilisation (51\%) and for Ancient History as 11-20 (41\%). GCSE class sizes were more varied, with the average GCSE class size reported as 1-5 in Greek (58\%), 6-10 for Ancient History (38\%) and 11-20 in Latin (38\%) and Classical Civilisation (37\%). However, Ancient History and Classical Civilisation were more likely to have higher class sizes and so a greater number of grades were initially downgraded in these subjects. For example, a teacher of A Level Ancient History in a state school in the North West reported that a pupil was marked down from a $\mathrm{C}$ to a $\mathrm{U}$ by the algorithm. Another teacher at a different state sixth form college in the North West reported that $70 \%$ of their CAGs in A Level Classical Civilisation were initially downgraded. They felt that '...the whole algorithm process has been a shambles and my professional judgement on CAGs insulted'.

It was also noted by some that there is normally a rush to complete the course, especially for those on a reduced timetable, and so the absence of exams benefitted their students. Other benefits came when the high grades of previous cohorts helped raise the CAGs and algorithm-awarded grades of the 2020 cohort, sometimes 
Table 1: Confidence in preparing for the 2021 GCSE exams as reported by respondents in response to question 5. Green represents the highest percentage of answers and red the lowest.

\begin{tabular}{|l|r|r|r|r|r|r}
\hline & $\begin{array}{c}\text { Extremely } \\
\text { confident }\end{array}$ & $\begin{array}{c}\text { Very } \\
\text { confident }\end{array}$ & Confident & $\begin{array}{c}\text { Not so } \\
\text { confident }\end{array}$ & $\begin{array}{c}\text { Not at all } \\
\text { confident }\end{array}$ & $\begin{array}{c}\text { Number of } \\
\text { respondents }\end{array}$ \\
\hline GCSE Latin & $14 \%$ & $9 \%$ & $44 \%$ & $26 \%$ & $7 \%$ & 117 \\
\hline GCSE Greek & $13 \%$ & $11 \%$ & $35 \%$ & $29 \%$ & $12 \%$ & 55 \\
\hline GCSE Ancient History & $17 \%$ & $17 \%$ & $33 \%$ & $25 \%$ & $8 \%$ & 12 \\
\hline GCSE Classical Civilisation & $5 \%$ & $9 \%$ & $30 \%$ & $35 \%$ & $21 \%$ & 66 \\
\hline
\end{tabular}

undeservedly so. At the same time other schools reported that a historically low-grade profile disadvantaged those in the 2020 cohort. The results of the CA's survey on the grade awarding process, then, reflect broader concerns reported by the sector more widely: (i) the unsuitability of the algorithm; (ii) the disadvantaging of candidates in state schools; (iii) the disadvantaging of candidates in cohorts of 15 or more; (iv) the use of historic data in determining student grades; and (v) the lack of moderation for CAGs.

\section{Preparing for 2021 examinations}

Question 5: 'After the interruption to the school year during lockdown and the move to home learning, how confident are you that you will be able to teach the full GCSE syllabus before the summer 2021 exams?'

The biggest concern reported by teachers in the survey was how adequately to prepare pupils for the 2021 examinations. The subject which teachers felt the most confident in was GCSE Latin. Of the 117 respondents who teach this subject, $44 \%$ said that they were confident and $23 \%$ were ether extremely or very confident in covering the full syllabus. There was a fairly even split between those who taught in the state and independent sectors and how they reported on this question, although those in the independent sector were more likely to class themselves as confident.

The subject that teachers felt least confident in was GCSE Classical Civilisation. Of the 66 respondents who taught this subject, $56 \%$ said they were either not so confident or not at all confident. The contrast is even starker when we consider the context of whether the respondents taught at either state/state selective or independent schools. Of the 14 respondents who taught in the state sector, 79\% reported being not so confident or not at all confident. By contrast, of the 49 respondents who taught this subject in the independent sector, $49 \%$ reported being not so confident or not at all confident.

Concern was raised for teaching GCSE Greek by $41 \%$ of respondents, especially as it is often taught off-timetable or as 'Gratin' on a reduced timetable alongside or combined with Latin. This was particularly notable in state/state selective schools, where five of the eight respondents said that they were not so confident or not at all confident that they would be able to teach the entire course. The other three said that they were confident, with no one either extremely or very confident. In the independent sector, $36 \%$ of the 47 respondents were not so confident or not at all confident, $34 \%$ were confident and $30 \%$ were either extremely or very confident. It is clear that at GCSE level Classical Civilisation and Greek are particular causes of concern for state sector teachers, who are more likely to feel under pressure and not able to cover the course satisfactorily.

Question 6: 'After the interruption to the school year during lockdown and the move to home learning, how confident are you that you will be able to teach the full A Level syllabus before the summer 2021 exams?'
Table 2: Confidence in preparing for the 2021 A Level exams as reported by respondents in response to question 6 . Green represents the highest percentage of answers and red the lowest.

\begin{tabular}{|l|r|r|r|r|r|r}
\hline & $\begin{array}{c}\text { Extremely } \\
\text { confident }\end{array}$ & $\begin{array}{c}\text { Very } \\
\text { confident }\end{array}$ & Confident & $\begin{array}{c}\text { Not so } \\
\text { confident }\end{array}$ & $\begin{array}{c}\text { Not at all } \\
\text { confident }\end{array}$ & $\begin{array}{c}\text { Number of } \\
\text { respondents }\end{array}$ \\
\hline A Level Latin & $19 \%$ & $16.5 \%$ & $41.5 \%$ & $20 \%$ & $3 \%$ & 96 \\
\hline A Level Greek & $15 \%$ & $18 \%$ & $42.5 \%$ & $21.5 \%$ & $3 \%$ & 33 \\
\hline A Level Ancient History & $10 \%$ & $0 \%$ & $55 \%$ & $20 \%$ & $15 \%$ & 20 \\
\hline A Level Classical Civilisation & $6 \%$ & $9 \%$ & $41 \%$ & $34 \%$ & $10 \%$ & 100 \\
\hline
\end{tabular}

On the whole, confidence was slightly higher at A Level than at GCSE for preparing for the 2021 exams and there was little difference in how state/state selective and independent school teachers answered this question for all subjects.

For A Level Latin, Greek and Ancient History there was a general feeling of confidence with a higher proportion reporting that they were confident or even very/extremely confident that they would finish the course. Nevertheless, it was acknowledged that while most A Level pupils, particularly in Latin and Greek, were able to work independently, others 'struggled hugely with engagement' and that A Level pupils are not always as motivated as the government think they are. Classical Civilisation again appeared to be the subject that caused the most concern. Of the 100 respondents who teach this subject at A Level, $44 \%$ were either not so confident or not at all confident.

The main reason for this concern about Classical Civilisation at both GCSE and A Level was over how teachers would adequately cover the course content following the loss of face-to-face teaching time during lockdown. The content for both levels was already felt to be excessive and 'very difficult to manage in two years'. The World of the Hero module at A Level was singled out as not only being particularly content-heavy but also one of the earliest exams in the calendar and hence an 'annual concern' to cover the syllabus. The current crisis and lost teaching time have only exacerbated these problems and made teaching these courses to an adequate standard even harder.

Many also noted that while they may have time to teach the content before next summer, there will be little time left for revision and practising exam skills. This is obviously a potential problem for all subjects, not just Classical Civilisation. Even those who were able to cover sufficient content through online learning questioned how much pupils actually learned during that time. Significant revision will be needed and many fear there will not be enough time. Further concerns were raised about the new GCSE Classical Civilisation qualification, as the 2019 results were 'mystifying and disappointing in equal measure'. Not only had this affected CAGs for the 2020 cohort, as they were based on historic data from the previous cohort, but it also makes it harder to prepare pupils for the exam, as teachers felt it was not always clear what the exam board expects. This concern is further evident in the Facebook groups for OCR Classical Civilisation and Ancient History, on which there are several threads asking what the exact requirements of the exams are, as well as discussing the necessity of including scholarship and resources to practise this skill.

\section{Ofqual consultation on 2021 examinations}

Question 7: 'How satisfied were you with the consultation process for the changes made by Ofqual to the 2021 exams?'

From the total of 164 respondents, $40 \%$ said they were dissatisfied with Ofqual's consultation process, $27 \%$ very dissatisfied and $26 \%$ neither satisfied nor dissatisfied, leaving $6 \%$ satisfied and less than $1 \%$ very satisfied. 
Q7: How satisfied were you with the consultation process for the changes made by Ofqual to the 2021 exams?

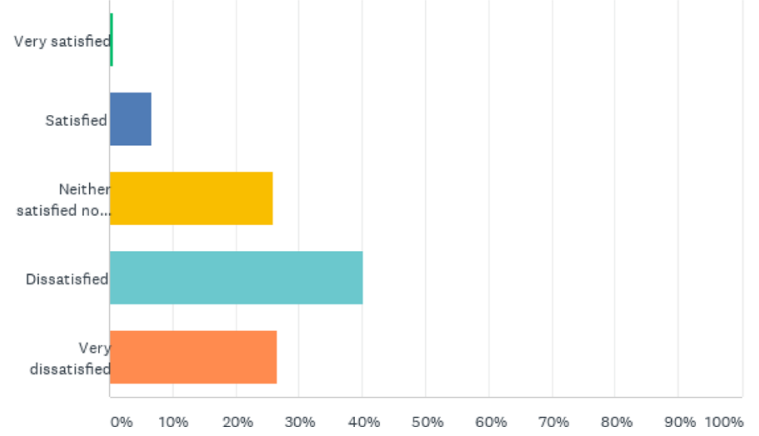

Graph 2: Levels of teacher satisfaction with Ofqual's consultation process as reported in response to question 7 .

The split between state/state selective and independent school teachers on this question was equal for those who said they were dissatisfied ( $40 \%$ for state sector and $42 \%$ for independent). However, state sector teachers were more likely to say that they were very dissatisfied (32\%) than those in independent schools (18\%). The overriding reaction to the consultation process was therefore negative, especially in the state sector, with many feeling that classical subjects had been ignored. Ten respondents said they had not been aware of it and that it had been poorly publicised during the summer holiday, with one asking: 'What consultation process?'

For those who were aware of the consultation, they commented on the apparent disparity between the treatment of classical subjects and that of other subjects. 23 respondents commented that it was unfair to reduce assessment content in some subjects but not others, as changes were only made to how GCSE English, Geography, History and Ancient History will be examined (Ofqual, 2020b). This was felt particularly strongly with GCSE Classical Civilisation, for the reasons already discussed in regards to the heavy syllabus content. It was also felt that '...the lack of concession to the effect of lockdown will increase the divide between state and independent school attainment'. One teacher at a state grammar in the Home Counties said, 'As a state school, we have been unable to teach video lessons due to lack of technology. Whilst we have tried to cover as much syllabus as we can remotely, we are at an obvious and significant disadvantage to private schools which have been able to offer a full timetable of video lessons'.

There is also real concern that classical subjects will perform poorly in comparison to other subjects that have had content cut and this could have a detrimental impact on future recruitment into the subject and the tenability of small departments with low pupil numbers. This is a problem faced by departments in both state and independent sectors. A teacher at an independent school in the Midlands said, 'This does not help in the relentless battle to maintain our place in the school curriculum'. Our hope must be that if there are adverse effects on results in 2021 these are shortlived and that results and recruitment bounce back, while senior leadership teams overlook any dip in attainment.

\section{Moving forward}

Teaching and learning varied between schools and individual pupils to such an extent during lockdown that pupils have started this academic year with vastly differing levels of knowledge and understanding. Many respondents raised concerns about the ongoing impact this will have on pupils from disadvantaged backgrounds and pupils with SEND requirements. Moreover, a teacher at an independent school in Oxfordshire expressed concern for their international pupils who study Classical Civilisation as they were not always able to engage with online learning due to the time difference and are already disadvantaged as they are less likely to have studied ancient Greek and Roman history and culture before they start the course. There is also a fear amongst respondents that future school closures will have further negative consequences for pupils. Indeed, after only a month back at school, many teachers and pupils have already missed two weeks of school after needing to self-isolate and questions have been raised over how schools will continue to run safely if too many staff have to isolate at home (Ferguson, 2020).

Many respondents asked that the DfE and Ofqual make further changes to the syllabus and exam format for 2021. This request was supported by the unions in a letter to Gavin Williamson, Education Secretary, in August 2020: 'Most urgently, robust systems must now be developed to ensure that the 2021 grade awarding process for GCSE and A Level is reliable, valid and secure. We are concerned that the current arrangements do not meet these criteria' (Bousted \& Courtney, 2020). A suggestion for Classical Civilisation and Ancient History at A Level was to offer a greater choice of essay questions and to remove the requirement to comment on secondary scholars for Classical Civilisation. There was also a call from respondents to remove the English-Latin/Greek sentences at GCSE. It is unclear whether the DfE and Ofqual will be prepared to make further changes but as one respondent commented, 'If Ofqual can issue potentially life-changing A Level results and then change things a few days later, surely they can still review arrangements for the 2021 exams'. If further changes are made, for example to the timing of exams, these changes must be announced as early as possible to give teachers a chance to adapt their teaching as necessary.

It was acknowledged that OCR has tried to help teachers by extending the current cycle of set texts for a further year. Sadly, this came too late for those who had already started preparing AS set texts for examination in summer 2021. ${ }^{2}$ The examination board Eduqas, on the other hand, was found to be 'very unhelpful'. A large number of respondents felt let down by the bodies responsible for setting and delivering exams. It was felt that the Classics community was 'completely ignored' and Ofqual instead focused on subjects with larger candidate numbers. Another respondent felt that '...nothing Ofqual does puts the interests (and in particular the mental health) of students first'. It was felt that greater willingness from officials to work with teachers would be needed in order to move forward and to avoid such problems in the future.

The survey showed the level of discontent amongst the Classics teaching community but also the overwhelming concern felt for the wellbeing and academic attainment of our pupils. The frustration and sense of unfairness over Ofqual's consultation process is a real concern and risks damaging the good will of teachers who often already teach classical subjects on reduced time or off timetable. This period has clearly been stressful and concerning for pupils. However, it must also not be forgotten that teachers have been working under significant burdens, many with increased workloads, caring responsibilities and levels of stress. A real concern must then be the damage that this causes to the mental health and wellbeing of teachers and the loss of those who leave the profession as a result.

The Classical Association Teaching Board will continue to champion the teaching and learning of classical subjects in schools. Its members will use the data from the Teachers' Survey to inform 
discussions and raise these concerns with multiple stakeholders. The Teaching Board includes a representative member for each classical subject, who convenes a working group, responding to urgent issues, between meetings. Teachers are encouraged to contact the subject representatives (listed below) to feed into these discussions.

Ancient History: Dr April Pudsey, Manchester Metropolitan University

Classical Civilisation: Rob Hancock-Jones, Townley Grammar School

Greek: Dr Chris Burnand, Abingdon School

Latin: Dr Aisha Khan-Evans, Kings College London

They can be contacted via the CA office: office@ classicalassociation.org

\section{Appendix - CATB survey}

GCSE and A level Results 2020

Through its Teaching Board the Classical Association monitors developments affecting the teaching of classical subjects and liaises with exam boards to support Classics subject provision.

The results of this survey will not be attributed to individual respondents or schools. You are invited to provide your contact details, if you wish to do so. This is so that we can identify possible case studies. If you would like a copy of your individual response, please email us at office@classicalassociation.org. This survey can be completed in under 10 minutes.

What type of school or college do you teach at?

State

State (selective)

Independent

Private student

Other (please specify)

What subject/s do you teach? Please tick all that apply.

GCSE Latin

GCSE Greek

GCSE Ancient History

GCSE Classical Civilisation

AS Latin

AS Greek

AS Ancient History

AS Classical Civilisation

A level Latin

A level Greek

A level Ancient History

A level Classical Civilisation

3. For the classes you taught at GCSE, AS and A level this year, what size were your class/classes?

Please give a number for all classes selected at Question 2.

1-5

6-10

$11-20$

21 or more

GCSE Latin

GCSE Greek

GCSE Ancient History

GCSE Classical Civilisation

AS Latin

AS Greek

AS Ancient History

AS Classical Civilisation

A level Latin

A level Greek
A level Ancient History

A level Classical Civilisation

Comments (optional)

4. What impact has the grade awarding process had on your students this year?

Very positive

Positive

Neutral

Negative

Very negative

Comments (optional)

5. After the interruption to the school year during lockdown and the move to home learning, how confident are you that you will be able to teach the full GCSE syllabus before the summer 2021 exams?

Extremely confident

Very Confident

Confident

Not so confident

Not at all confident

N/A

GCSE Latin

GCSE Greek

GCSE Ancient History

GCSE Classical Civilisation

Comments (optional)

6. After the interruption to the school year during lockdown and the move to home learning, how confident are you that you will be able to teach the full A Level syllabus before the summer 2021 exams?

Extremely confident

Very confident

Confident

Not so confident

Not at all confident

N/A

A level Latin

A level Greek

A level Ancient History

A level Classical Civilisation

Comments (optional)

7. How satisfied were you with the consultation process for the changes made by Ofqual to the 2021 exams?

Very satisfied

Satisfied

Neither satisfied nor dissatisfied

Dissatisfied

Very dissatisfied

Comments (optional)

8. Any other comments you would like to make about either this year's grade awarding process or preparing for the 2021 exams.

9. Would you be happy for the Classical Association to contact you for further information?

Yes

No

10. If Yes, at what email address would you like to be contacted?

11. Name of your school or college (optional)

12. Your name (optional)

\section{Notes}

1 I would like to express my thanks to Arlene Holmes-Henderson for her advice on this article. 
2 In a meeting with CATB since this article was first written, a representative from OCR said that special considerations would be put in place for pupils who have been negatively affected by this change.

\section{References}

Adams R (2020) 'Nearly $40 \%$ of A-level result predictions to be downgraded in England'. The Guardian, 7 August 2020. Available online: https://www. theguardian.com/education/2020/aug/07/a-level-result-predictionsto-be-downgraded-england. (Accessed 28 September 2020).

Bousted M (2020) 'Summer 2020 grades for GCSE, AS and A level'. National Education Union, 3 April 2020. Available online: https://neu.org.uk/pressreleases/summer-2020-grades-gcse-and-level. Accessed 28 September 2020).

Bousted M and Courtney K (2020) 'Bigger changes needed for 2021' National Education Union, 19 August 2020. https://neu.org.uk/press-releases/biggerchanges-needed-2021. (Accessed 28 September 2020).

Brown A (2020) 'NEU: Government has its "head in the sand" over 2021 GCSEs and A-levels'. National Education Union, 4 August 2020. Available online: https://unionweb.co.uk/neu/neu-government-has-its-head-in-the-sandover-2021-gcses-and-a-levels/. (Accessed 28 September 2020).

Cowburn A (2020) 'A-Level results: Gavin Williamson facing backlash over grading system as private schools see biggest increase in top grades'. I News, 13 August 2020. Available online: https://www.independent.co.uk/news/uk/ politics/level-results-private-school-state-gavin-williamsongrades-a9669571.html. (Accessed 28 September 2020).

Cullinane C and Montacute R (2020) 'Covid-19 Impacts: School Shutdown". Sutton Trust. Available online: https://www.suttontrust.com/our-research/ covid-19-and-social-mobility-impact-brief/. (Accessed 28 September 2020).

Department for Education (2020a) 'Schools, colleges and early years settings to close'. Press release 18 March 2020. Available online: https://www.gov.uk/ government/news/schools-colleges-and-early-years-settings-to-close. (Accessed 28 September 2020).
Department for Education (2020b) 'Further details on exams and grades announced'. Press release 20 March 2020. https://www.gov.uk/government/ news/further-details-on-exams-and-grades-announced. (Accessed 28 September 2020).

Department for Education (2020c) 'Ofqual launches consultations on 2021 exams and assessments'. Press release 2 July 2020. https://www.gov.uk/ government/news/ofqual-launches-consultation-on-2021-exams-andassessments. (Accessed 28 September 2020).

Ferguson D (2020) 'Class sizes in the UK may rise to 60 as schools struggle to cover for self-isolating teachers'. The Guardian, 27 September 2020. Available online: https://www.theguardian.com/education/2020/sep/27/class-sizes-inuk-may-rise-to-60-as-schools-struggle-to-cover-for-self-isolating-teachers. (Accessed 4 October 2020).

Hall S (2020) 'Private school pupils twice as likely to receive online lessons than those at state schools'. I News, 20 April 2020. https://inews.co.uk/news/ coronavirus-private-school-twice-as-likely-to-receive-online-lessons-stateschools-420007. (Accessed 28 September 2020).

Nye P and Thomson D (2020) 'A-Level results 2020: Why independent schools have done well out of this year's awarding process'. Education DataLab, 16 August 2020. Available online: https://ffteducationdatalab.org.uk/2020/ 08/a-level-results-2020-why-independent-schools-have-done-well-out-ofthis-years-awarding-process/. (Accessed 28 September 2020).

Ofqual (2020a) 'Awarding qualifications in summer 2020'. Available online: https://assets.publishing.service.gov.uk/government/uploads/system/uploads/ attachment_data/file/887018/Summer_2020_Awarding_GCSEs_A_levels_-Info_for_Heads_of_Centre_22MAY2020.pdf. (Accessed 28 September 2020).

Ofqual (2020b) 'Exams and assessments in 2021'. Available online: https://www. gov.uk/government/news/exams-and-assessments-in-2021. (Accessed 28 September 2020).

Williams Z (2020) 'The UK's exam results farce only deepens the inequality between private and state pupils. The Guardian, 10 August 2020. Available online: https://www.theguardian.com/commentisfree/2020/aug/10/examresults-inequality-private-state-students. (Accessed 28 September 2020). 